Article

\title{
Performance of the RegCM4.6 for High-Resolution Climate and Extreme Simulations over Tibetan Plateau
}

\author{
Huanghe $\mathrm{Gu}^{1,2,3, * \mathbb{D} \text { and Xiaoyan Wang }}{ }^{1}$ \\ 1 State Key Laboratory of Hydrology-Water Resources and Hydraulic Engineering, Hohai University, \\ Nanjing 210098, China; xywang@hhu.edu.cn \\ 2 Joint International Research Laboratory of Global Change and Water Cycle, Hohai University, \\ Nanjing 210098, China \\ 3 College of Hydrology and Water Resources, Hohai University, Nanjing 210098, China \\ * Correspondence: ghh0001@hhu.edu.cn; Tel.: +86-137-7096-0371
}

Received: 7 September 2020; Accepted: 12 October 2020; Published: 15 October 2020

\begin{abstract}
This paper presents an evaluation of the Regional Climate Model version 4.6.1 (RegCM4) at a high-resolution simulation at $10 \mathrm{~km}$ applied over the Tibetan Plateau. This simulation covers the period from 1980 to 2010 and is nested in a RegCM4 simulation at 30-km resolution, which is driven by the main European Centre for Medium-Range Weather and Forecasting reanalysis (ERA-Interim reanalysis) dataset. A new daily observational dataset is employed as reference data to evaluate the temperature and precipitation simulations for the inner model domain and the five largest river basins that originated in the Tibetan Plateau (TP) (i.e., the source region of Yangtze River, Yellow River, Mekong River, Salween River, and Brahmaputra River). In comparison with the low-resolution model run (R30), the cold biases for the area-averaged temperature were reduced from -2.5 to $-0.1^{\circ} \mathrm{C}$ and the wet biases in summer mean precipitation were reduced from $58 \%$ to $25 \%$ in the high-resolution model run (R10). The substantial warming trends and slight wetting trends were basically reproduced by both RegCM4 simulations. Annual mean precipitation trends from both simulations show a better agreement with the observations than the ERA-Interim, which underestimates the annual mean precipitation trends in most regions, whereas both the RegCM4 and ERA-Interim consistently underestimate the annual mean temperature trends when compared with the observations. In addition, the overall improvement in the modeling trends for annual mean temperature and precipitation in R10 is limited when compared with R30. The extreme precipitation was also captured reasonably in both RegCM4 simulations, and the better performance is detected in the R10 simulation. The findings above show that RegCM4 with a high-resolution of $10 \mathrm{~km}$ is capable of reproducing the major regional climate features over the TP, but a great deal of uncertainties still exist, especially in the subregion of the Brahmaputra River basin. Thus, the 10-km resolution simulation in RegCM4 may still not be fine enough to resolve the topoclimates over the complex Himalayan terrain in the Brahmaputra River basin.
\end{abstract}

Keywords: regional climate modeling; extreme events; RegCM4; uncertainty; Tibetan Plateau

\section{Introduction}

The Tibetan Plateau (TP) with the mean altitude over $4000 \mathrm{~m}$ above the sea level is termed as "the third pole" because it is the highest and largest continental plateau on the earth [1,2]. Its unique terrain and specific underlying surface can have a great effect on not only regional climate but also the global atmospheric circulation [3,4]. The TP is also recognized as the "water tower of Asia" owing to that it is the source of a number of major rivers in Asia, including the Indus, Ganga, Brahmaputra, 
Mekong, Salween, Yangtze, and Yellow River, which support the livelihood and environment of more than 1.4 billion people [5]. The warming trend of the TP regions is very significant and higher when compared with that in the regions at similar latitudes elsewhere [6,7]. In addition to the significant warming, a slight rising trend in precipitation is also apparent in the TP $[4,8,9]$. Climate change in the $\mathrm{TP}$ and its impacts draw interests from academics worldwide [10-16].

Accurately simulating and predicting climate change regimes over the TP are still a particular challenge for general circulation models (GCMs), which are considered to be an important tool used for predictions of future climate. This is largely on account of the lack of understanding of complex interactions between local and remote processes, unresolved subgrid-scale processes, and the lower resolutions applied in coupled GCMs. For instance, CMIP5 GCMs presented poor performance in the simulations of temperature, precipitation, snow cover, and wind speed over the TP [17-20]. Regional climate models (RCMs), which can describe well the mesoscale atmospheric processes, surface process (i.e., land surface characteristics and coast line), and other factors that directly impact the modeling of climate variations, have been commonly employed to investigate regional climatic changes in historical and future periods [21].

Numerous studies have shown that RCMs are capable of remarkably advancing the accuracy of climate feature simulations over the TP compared with GCMs [22]. More specifically, the well-known prominent wet bias in the precipitation and cold bias in temperature over the TP [19] is largely constrained in the GCMs. Gao et al. [23] found that the observed change patterns and especially the elevation-dependent warming was captured better by an RCM compared with the reanalysis or GCMs, which are used as their boundary condition. In recent decades, more researchers focused on the effects of different model configurations (i.e., the resolution [22,24], cumulus convective schemes [25], boundary forcing datasets $[26,27]$, and land surface schemes $[28,29])$ on the performance of RCM in simulating historical or future climate over the TP.

Variability and trends in climate extremes bring greater direct impacts on human and natural systems than those from mean values, and they have gained increasing attention in recent years [30,31]. In the TP, some studies show an increasing trend for the proportion of extreme precipitation to total precipitation in the period of 1974-2014 [32], but it still needs further investigation and explanation. Additionally, understanding the spatial and temporal distribution of possible changes in extreme climate events is also important for water resources managers on a basin level. A whole host of studies have shown that the response of the basin hydrological processes to climate change will be varied with the rivers [33]. Therefore, climate scenarios need to be developed for specific basins looking at water sectors [34].

This study is a continuation of our previous research [35]. Distinguished from the reported climate change modeling experiments conducted over the TP in the past, the high-resolution climate simulations from RegCM4 are evaluated in this study. The specific aims in this work are as follows:

(1) Undertaking a comprehensive evaluation of a 32-year high-resolution regional climate simulation of historical temperature and precipitation from the RegCM4 model against state-of-the-art observation over the whole TP and five river basins located in the TP.

(2) Assessing the performance of RegCM4 in reproducing precipitation extremes over the TP.

(3) Determining the potentialities and limitations of the RegCM4 simulation over the TP and investigating the effects of horizonal resolution $(30 \mathrm{~km}$ and $10 \mathrm{~km}$ ) on the accuracy of climate features modeling.

This paper is organized as follows: Section 2 describes the study domain, the adopted model, data, and climate indices. The evaluation results are shown in Section 3. Finally, the main conclusions and summaries are presented in Section 4. 


\section{Material and Methods}

\subsection{The Regional Climate Model}

The recent version 4.6.1 of the nonhydrostatic regional climate model RegCM (hereafter RegCM4) is applied in this study. It is developed and extended by the Abdus Salam International Centre for Theoretical Physics (ICTP) [36,37]. RegCM4 has been widely employed for climate simulations at the regional scale, such as the whole of China, East Asia [38-41], as well as the TP [35,42,43]; and it is selected as one of the RCMs used for the Coordinated Regional climate Downscaling Experiment (CORDEX) [44]. Based on the performance of different physical parameterization options reported in past studies, here, the RegCM4 parameterization schemes applied in this work consist of the moisture scheme with the subgrid scale [37], the radiation scheme of the National Center for Atmospheric Research community climate model version 3 (CCM3) [45], the Holtslag boundary layer scheme [46], Emanuel cumulus scheme [47], Zeng ocean surface schemes [48], and CLM4.5 land surface model [49].

In this work, a one-way nesting approach with two domains D1 and D2 was configured in RegCM4 at 30 and $10 \mathrm{~km}$ horizontal resolution, respectively (Figure 1). The outer domain D1 was centered at $31^{\circ} \mathrm{N}-94^{\circ} \mathrm{E}$, with $250 \times 220$ grid points. The D1 domain is large enough to cover the vast Asian highlands and some important terrain characteristics areas such as the Bay of Bengal and parts of the Arabian Sea, from which the main moisture of monsoonal precipitation prevailing over the TP is sourced [50-52]. The D2 domain was nested in the outer domain, with $380 \times 232$ grid points, cover the whole TP. This can ensure that the resolution of the inner domain matched the resolution of the gridded observational dataset. The simulations conducted in both domains referred to 18 vertical layers with the model top set at $50 \mathrm{hPa}$ in this study.
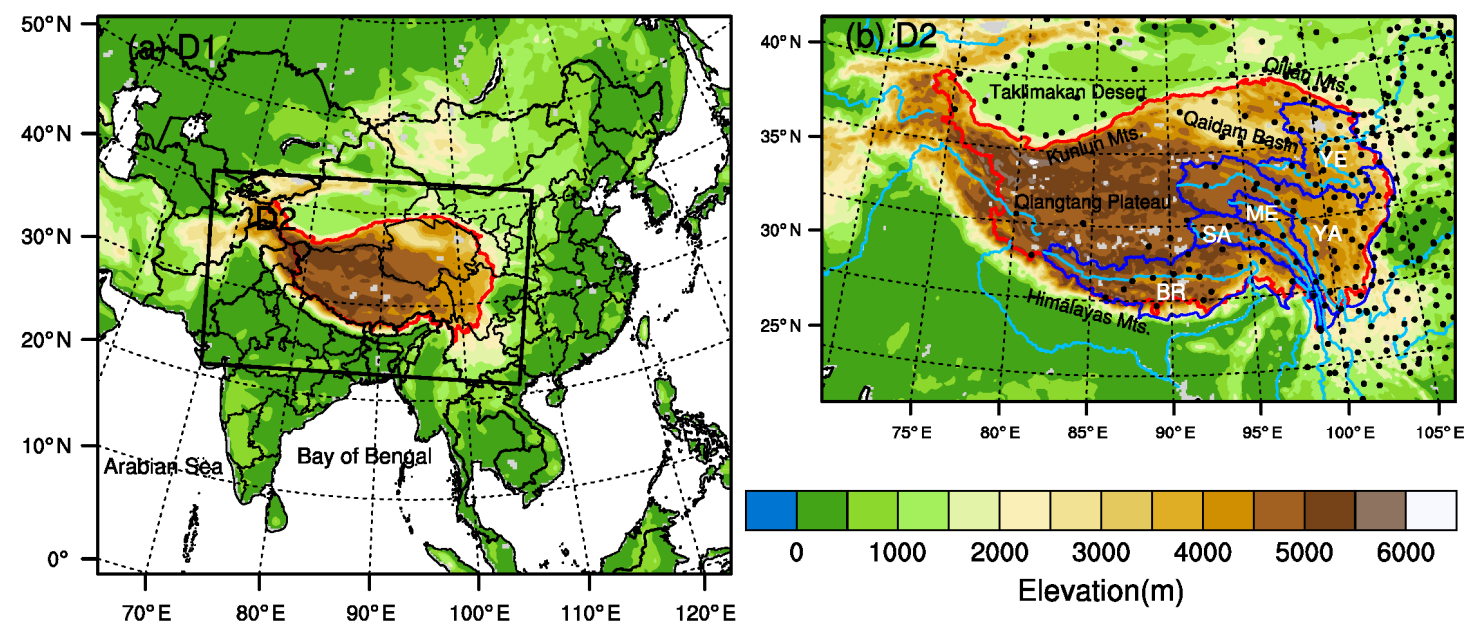

Figure 1. Domain configuration of the nested nonhydrostatic regional climate model RegCM (RegCM4) simulations with $30-\mathrm{km}$ resolution (a) as well as $10-\mathrm{km}$ resolution (b) and the study area including the Tibetan Plateau and the source region of five major river originated in the TP. Note that YE, YA, ME, SA, and BR represent the Yellow River, Yangtze River, Mekong River, Salween River, and Brahmaputra River. The meteorological stations applied for constructing the observational dataset are marked by black dots (modified from Gu et al. [35]).

The 6 hourly ERA-Interim reanalysis dataset is applied to drive the climate model. The ERA-Interim selected as the lateral boundary conditions can be considered to be of very high quality [53], particularly in the TP, and it shows close agreement with observations [54,55]. The weekly sea surface temperature from the National Oceanic and Atmospheric Administration (NOAA) is also used to drive the model [56]. The model simulations were run continuously from 1 January 1979 to 31 December 2010. The year 1979 was used to spin-up the model and was not used in the analysis. 
This study is devoted to the investigation of RegCM4 model performance as a first step toward the long-term future climate projection and its impact on the water balance in large river systems on the TP. Therefore, some analysis is also performed over five large river basins (i.e., the source region of Yangtze River, Yellow River, Mekong River, Salween River, and Brahmaputra River), laying the foundation for the investigations in regard to the response of hydrological processes in these river basins to climate change in the near future, on the basis of the coupling of RegCM4 and hydrological models.

\subsection{Observational Datasets and Chosen Indicators}

A newly compiled gridded daily meteorological dataset at $0.1^{\circ}$ spatial resolution [57], covering the period from 1979 to 2018 , is applied as the reference data to validate the model simulations. It was compiled based on gauge-observed data (as shown in Figure 1) obtained from the China Meteorological Administration and other datasets such as satellite precipitation data and Global Land Data Assimilation System data $[58,59]$. The high-resolution elevation data were introduced in the observed air temperature interpolation [57]. The finest scale for model performance evaluation depends on the grid spacing of the observation. To match the spatial resolution of the simulation, the observation datasets are remapped to the corresponding model grids (i.e., $30 \mathrm{~km}$ and $10 \mathrm{~km}$ ) using the bilinear interpolation method to ensure a fair evaluation. In addition, the ERA-Interim reanalysis dataset is used in this work to investigate the added value of the regional climate model when compared with their forcing data and the limitations in the ERA-Interim reanalysis dataset.

In addition to the mean climate, we also assess the performance of the RegCM4 in reproducing climate extremes indicators. These extreme indicators shown in Table 1 cover the intensity, frequency, and duration aspects of extreme precipitation defined by the Expert Team on Climate Change Detection and Indices [60].

Table 1. Precipitation extreme indicators used in this study.

\begin{tabular}{ccc}
\hline Acronym & Definition & Unit \\
\hline RX1DAY & Maximum daily precipitation & $\mathrm{mm} /$ day \\
SDII & Simple daily intensity index (the annual total precipitation divided by the & $\mathrm{mm} /$ day \\
R10MM & Heavy precipitation days (days with daily precipitation larger than $10 \mathrm{~mm}$ ) & day \\
CDD & Consecutive dry days index (days with daily precipitation less than $1 \mathrm{~mm}$ ) & day \\
CWD & Consecutive wet days index & day \\
\hline
\end{tabular}

\section{Results}

In this section, the simulated surface air temperature and precipitation from RegCM4 are compared with observation to evaluate the ability of RCMs to reproduce the regional climate over the TP. To allow for direct comparison between the low-resolution model run (R30) and high-resolution model run (R10), the larger R30 domain has been limited to the extent of the R10 domain.

\subsection{Spatial Pattern of Seasonal Mean Temperature and Precipitation}

Our analysis first focuses on the evaluation of simulated surface air temperature. Figure 2 depicts the climatological seasonal means of observed and simulated surface air temperature and their mean biases for the period 1980-2010. Both R30 and R10 simulations could reproduce the spatial patterns of the observed temperature, which are characterized by a warmer climate in the southeastern and northern parts because of lower elevations but lower temperature in the western and central parts because of higher elevations. However, R30 underestimates the temperature in large parts of the domain, especially in the western TP. The area-averaged temperature shows a systematic cold bias approximating $-2{ }^{\circ} \mathrm{C}$; and in spring (form March to May, MAM), this bias increase to $-4{ }^{\circ} \mathrm{C}$, especially in the western TP (as shown in Table 2). Considering that the annual mean biases are $-2.5^{\circ} \mathrm{C}$ for R30 and $-0.1{ }^{\circ} \mathrm{C}$ for R10, respectively, the cold bias for the area-averaged air temperature is thus weakened 
in the R10 simulation. However, a slightly warm bias from the R10 simulation could be found in north and east part of the TP. On the whole, the biases for R30 are slightly larger than those in the higher resolution simulation R10. These results are similar to the findings from $\mathrm{Xu}$ et al. [22], who investigate the impact of horizontal resolution on climate simulation over the TP on the basis of the REMO regional climate model.

(a)

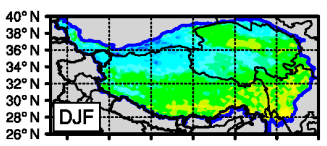

巡

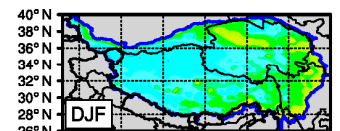

$\stackrel{\circ}{\check{x}}$

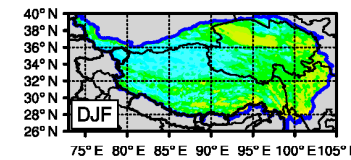

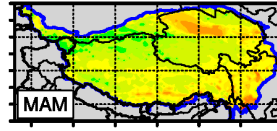
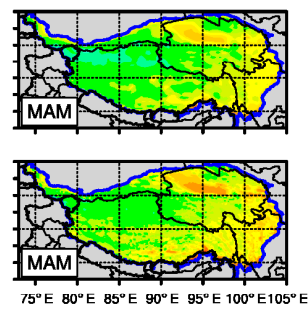
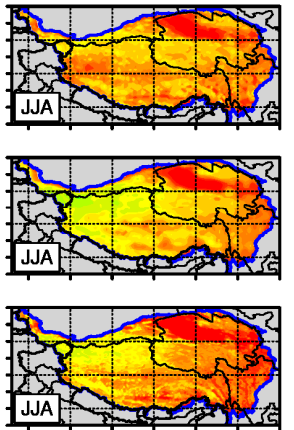

$75^{\circ} \mathrm{E} 80^{\circ} \mathrm{E} 85^{\circ} \mathrm{E} 90^{\circ} \mathrm{E} 95^{\circ} \mathrm{E} 100^{\circ} \mathrm{E} 105^{\circ}$

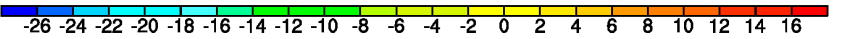

(b)
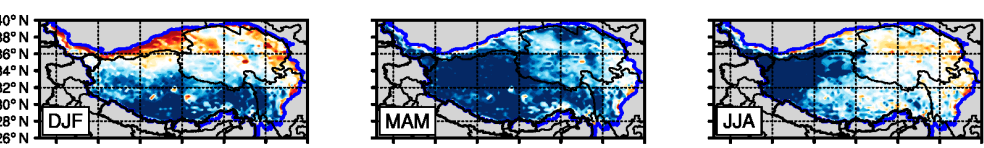

을

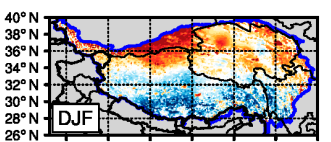

$75^{\circ} \mathrm{E} 80^{\circ} \mathrm{E} 85^{\circ} \mathrm{E} 90^{\circ} \mathrm{E} 95^{\circ} \mathrm{E} 100^{\circ} \mathrm{E} 105^{\circ} \mathrm{E}$
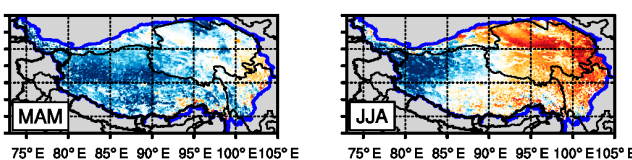

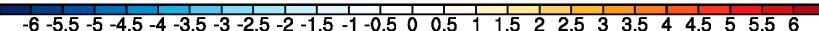
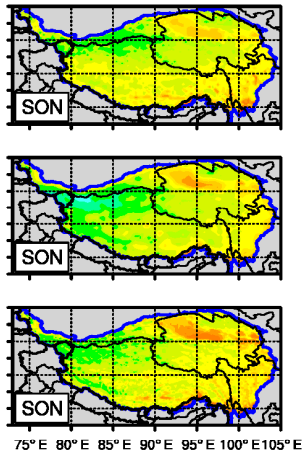

${ }^{\circ} \mathrm{C}$
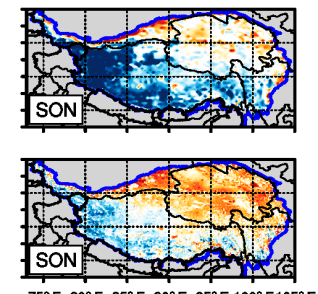

${ }^{\circ} \mathrm{C}$

Figure 2. The spatial distribution of simulated seasonal mean temperature (a, top panel) and mean biases (b, bottom panel) between the simulations and observations for 1980-2010.

Table 2. The mean bias (BIAS), root mean square error (RMSE), and the spatial correlation coefficients (SCOR) for seasonal temperature and precipitation between RegCM4 simulations and the observation.

\begin{tabular}{ccccc}
\hline & \multicolumn{2}{c}{ Temperature $\left({ }^{\circ} \mathbf{C}\right)$} & \multicolumn{2}{c}{ Precipitation $(\mathbf{m m} /$ day $)$} \\
\cline { 2 - 5 } & $\mathbf{R 3 0}$ & $\mathbf{R} 10$ & $\mathbf{R 3 0}$ & $\mathbf{R 1 0}$ \\
\hline BIAS & & & & \\
Winter (DJF) & -1.56 & 0.47 & 0.62 & 0.78 \\
Spring (MAM) & -4.58 & -2.29 & 0.87 & 0.81 \\
Summer (JJA) & -2.37 & 0.59 & 1.4 & 0.5 \\
Autumn (SON) & -1.83 & 0.69 & 1.06 & 1.03 \\
RMSE & & & & \\
DJF & 4.35 & 3.03 & 1.03 & 1.27 \\
MAM & 5.52 & 3.27 & 2.17 & 2.2 \\
JJA & 4.56 & 3.37 & 6.24 & 2.2 \\
SON & 3.93 & 2.44 & 3.02 & 2.59 \\
SCOR & & & & \\
DJF & 0.71 & 0.85 & 0.48 & 0.38 \\
MAM & 0.84 & 0.91 & 0.65 & 0.6 \\
JJA & 0.74 & 0.82 & 0.37 & 0.48 \\
SON & 0.77 & 0.87 & 0.48 & 0.51 \\
\hline
\end{tabular}

The accurate representation of precipitation remains a challenge for current global and regional climate models. The seasonal precipitation simulations and the mean biases for the TP are presented in Figure 3. The spatial patterns of the precipitation from R30 and R10 are similar, which is featured by increasing precipitation from the northwest to the southeast. The simulated heavy precipitation is 
concentrated in the southeast region along the southern slopes of the Himalayas, which are mainly brought on by the monsoon, the westerlies, and local convective activities. In winter, R30 and R10 tend to overestimate the precipitation over most areas of the TP. Similar patterns with wet biases in the western TP and dry biases in the eastern TP are shown in spring and autumn. In summer, the precipitation is underestimated over the central and northern $\mathrm{TP}$, with the largest underestimation up to $2 \mathrm{~mm} /$ day occurring in the central TP. On the contrary, the summer precipitation is overestimated by $2-5 \mathrm{~mm} /$ day over the boundary areas, especially the southeast TP.

(a)

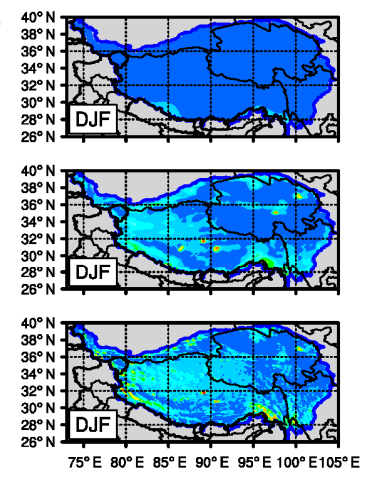

(b)

क्ष

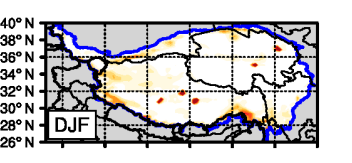

옹

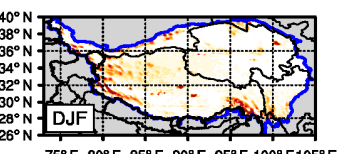

$75^{\circ} \mathrm{E} 80^{\circ} \mathrm{E} 85^{\circ} \mathrm{E} 90^{\circ} \mathrm{E} 95^{\circ} \mathrm{E} 100^{\circ} \mathrm{E} 105^{\circ} \mathrm{E}$
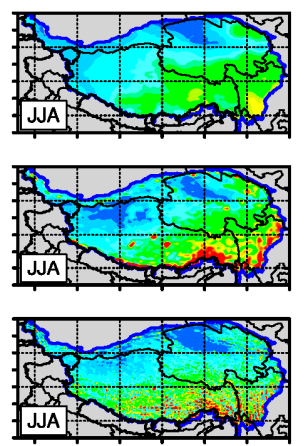

$75^{\circ} \mathrm{E} 80^{\circ} \mathrm{E} 85^{\circ} \mathrm{E} 90^{\circ} \mathrm{E} 95^{\circ} \mathrm{E} 100^{\circ} \mathrm{E} 105^{\circ} \mathrm{E}$

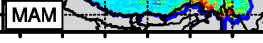

$75^{\circ} \mathrm{E} 80^{\circ} \mathrm{E} 85^{\circ} \mathrm{E} 90^{\circ} \mathrm{E} 95^{\circ} \mathrm{E} 100^{\circ} \mathrm{E} 105^{\circ}$
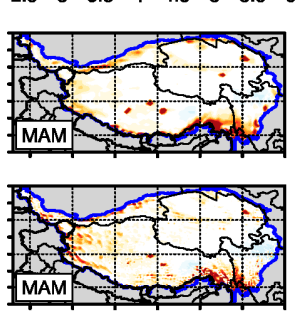

$75^{\circ} \mathrm{E} 80^{\circ} \mathrm{E} 85^{\circ} \mathrm{E} 90^{\circ} \mathrm{E} 95^{\circ} \mathrm{E} 100^{\circ} \mathrm{E} 105^{\circ}$

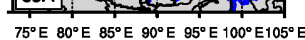

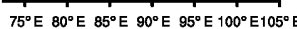

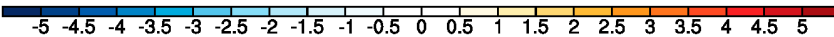

(c)
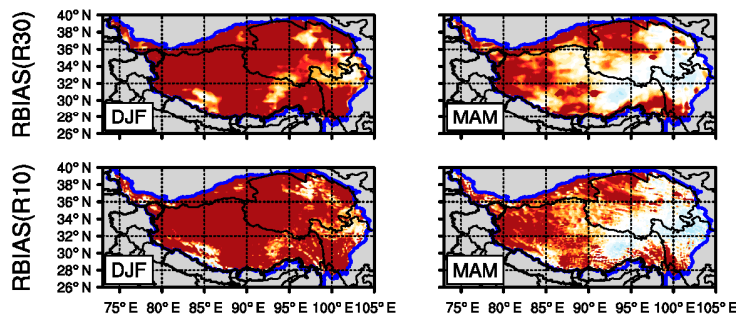

$95^{\circ} \mathrm{E} 100^{\circ} \mathrm{E} 105^{\circ} \mathrm{E}$
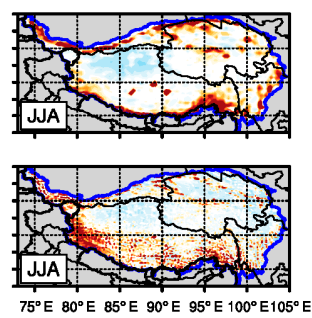

$75^{\circ} \mathrm{E} 80^{\circ} \mathrm{E} 85^{\circ} \mathrm{E} 90^{\circ} \mathrm{E} 95^{\circ} \mathrm{E} 100^{\circ} \mathrm{E} 105^{\circ} \mathrm{E}$

$\frac{1}{80} 100120140160180200$
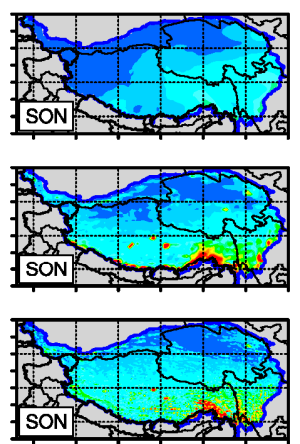

$75^{\circ} \mathrm{E} 80^{\circ} \mathrm{E} 85^{\circ} \mathrm{E} 90^{\circ} \mathrm{E} 95^{\circ} \mathrm{E} 100^{\circ} \mathrm{E} 105^{\circ} \mathrm{E}$

$\mathrm{mm} / \mathrm{day}$
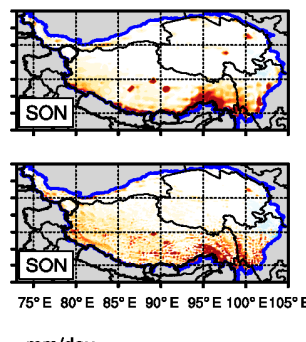

$\mathrm{mm} / \mathrm{day}$
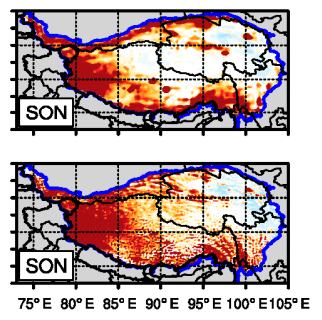

$\%$

Figure 3. Simulated seasonal mean precipitation (a, top panel) and biases (b, middle panel) for 1980-2010 in mm/day and relative biases (c, bottom panel) in percentage terms.

Taylor diagrams are constructed to synthetically evaluate the spatial scale performance of simulated seasonal mean temperature and precipitation (Figure 4) [61]. It is found that R30 and R10 have small differences in the standard deviations of simulated seasonal mean temperature, which indicate that they have similar abilities to capture the spatial variability of mean temperature as reflected by that the standard deviations values are similar to those from observation. In terms of the other evaluation indexes, better performance is obtained in R10 in comparison with R30, as reflected by higher spatial correlations (ranging from 0.82 to 0.91 ), lower bias, and lower RMSE error in all seasons. In general, R10 simulation produced a significant advantage in area-averaged temperature in each season. 

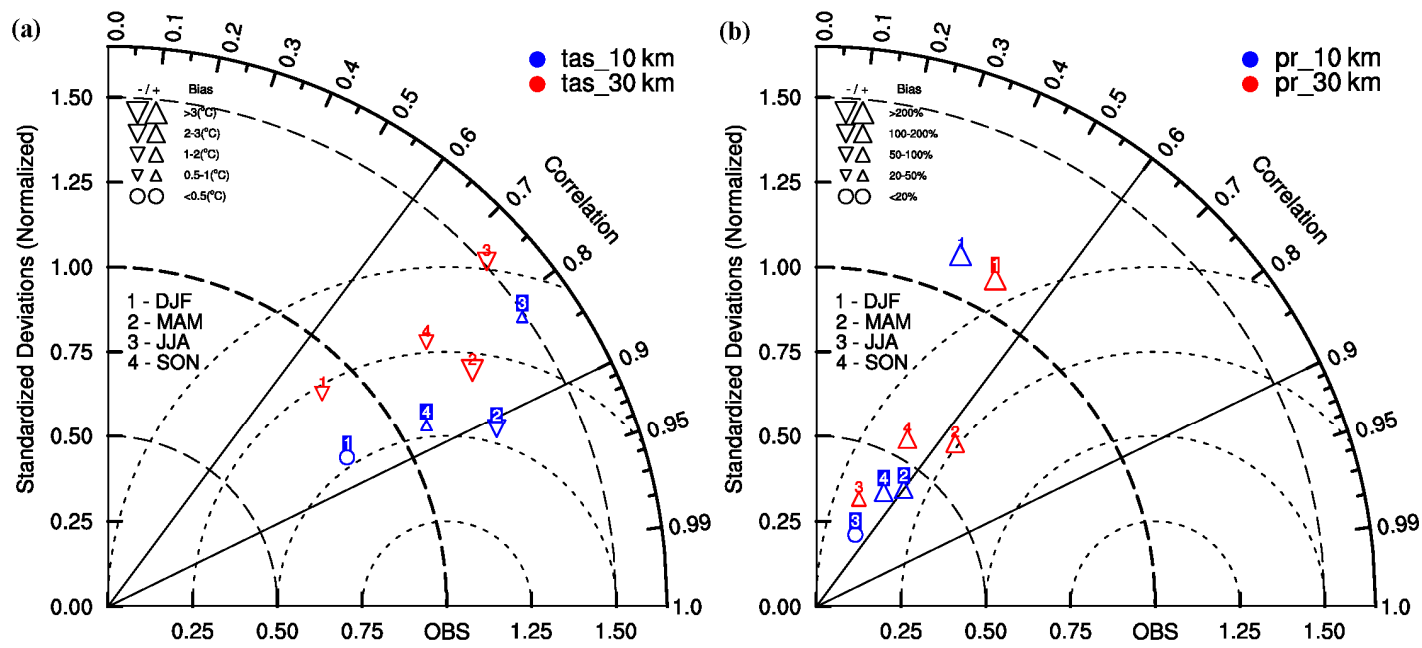

Figure 4. Taylor diagrams of simulated seasonal mean temperature (a, left panel) and precipitation (b, right panel) in relation to observation data over the whole TP for the period 1980-2010.

The difference between R30 and R10 in simulated seasonal precipitation is smaller than that in seasonal air temperature. Simulated precipitations are modeled reasonably at all seasons, with spatial correlation values in the interval [0.37, 0.65]. Variance ratios from R30 and R10 are both less than 1.0 in all seasons, except in winter (DJF), which indicates that the range of the simulated seasonal precipitation was lower than observation. Therefore, there is no evidence that a better performance in precipitation spatial pattern is obtained in the higher-resolution simulation.

\subsection{Interannual Variations of Annual Mean Temperature and Precipitation Anomalies}

It is important to assess the ability of RCMs to reproduce the observed decadal climate variability signals and trends given their application to future climate projections when driven by the boundary condition such as for ERA-Interim. As shown in Figure 5, simulated yearly mean air temperature anomalies over the entire TP and five river basins during the period 1980-2010 are compared with the observations. We find that the substantial warming trends for observed temperature are shown over the entire TP, especially in the Brahmaputra and Salween river basins. Both R30 and R10 are able to reproduce the interannual variations of the temperature as reflected by the correlation coefficients greater than 0.60 over most river basins in the TP. Moreover, in terms of yearly anomaly correlations and long-term trends, the two RegCM4 simulations show similar agreement compared with the ERA-Interim, although they tend to underestimate the trends when compared with observation. Thus, the underestimation of temperature trend is partly caused by limitations in the ERA-Interim forcing data. In addition, the evaluation suggests a limited improvement of temperature trends from the high-resolution simulation.

Figure 6 depicts the annual precipitation anomalies based on observation, reanalysis data, and two RegCM4 simulations over the TP and five subregions during 1980-2010. The correlation coefficients between simulated annual precipitation anomalies and observation are obviously lower than those of annual temperature anomalies. Nevertheless, the average of simulated correlation coefficients for annual precipitation anomalies over different regions reaches 0.55 in R30 simulation and 0.61 in R10 simulation, respectively, indicating that the RegCM4 model could basically reproduce interannual precipitation anomalies. Unlike the trend pattern of mean surface air temperature, regional precipitation in the TP shows persistent multi-year to decadal anomalies but no significant long-term trend. Only a slight increase trend (i.e., approximately $5 \%$ per decade) was identified over most regions based on the observation. By contrast, RCM-simulated annual precipitation trends in most regions are close to the observation and show significant improvement compared to the ERA-Interim reanalysis, indicating that the model is capable of reproducing the interannual variation of precipitation over the TP and five 
subregions. It is interesting to note that in terms of the trend and correlation coefficient, simulated annual mean precipitation anomalies from RegCM4 show a better agreement with the observations than the ERA-Interim, which underestimates the precipitation trends in most regions; however, this is not the case for the simulations of annual mean temperature.
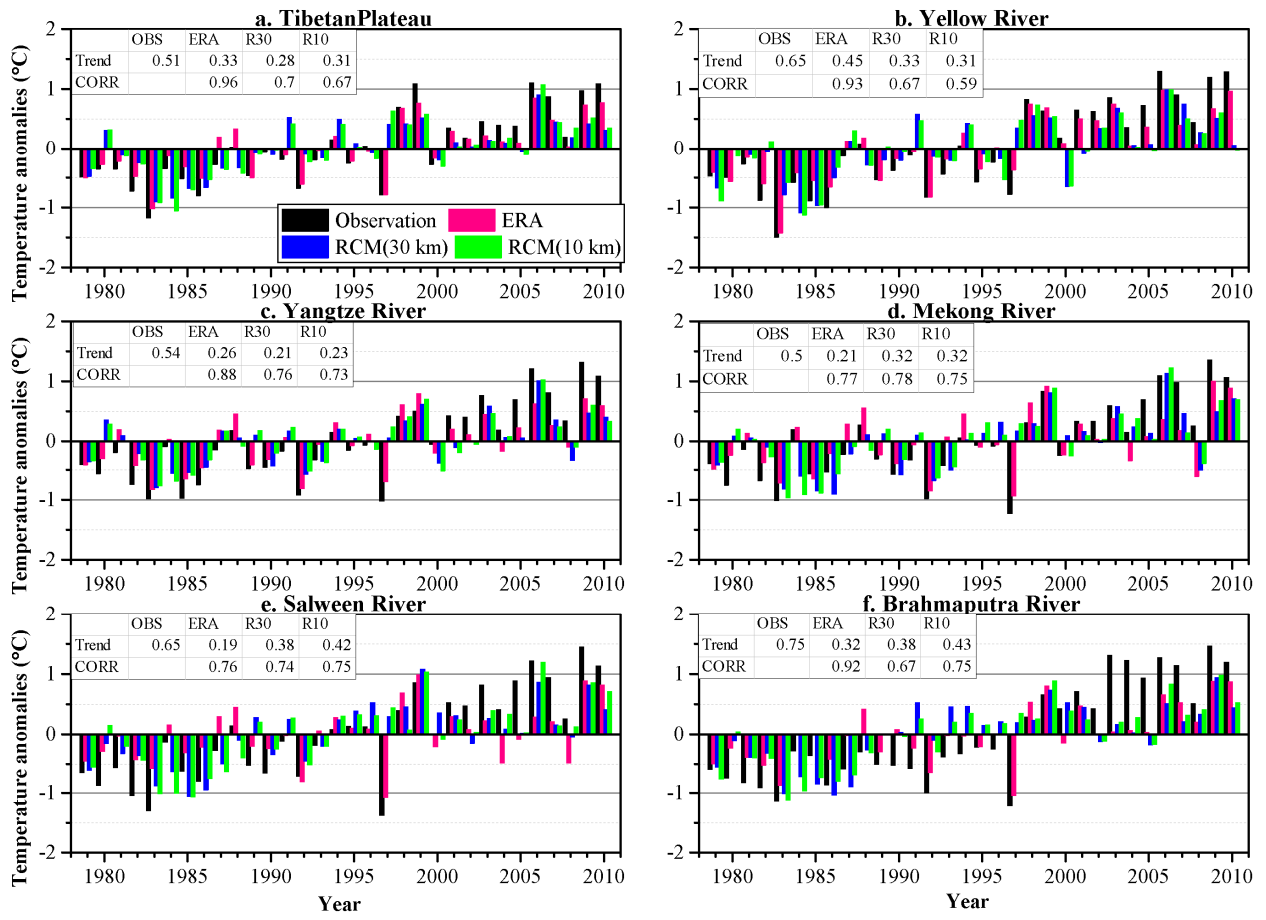

Figure 5. Annual mean temperature anomalies calculated from the observation, RegCM4 simulations, and the ERA-Interim reanalysis and the statistics (including the trend $\left({ }^{\circ} \mathrm{C} / \mathrm{decade}\right)$ and correlation coefficient (CORR for short)) between them over the whole Tibetan Plateau (TP) (a) and five river basins (b-f) for the period 1980-2010.
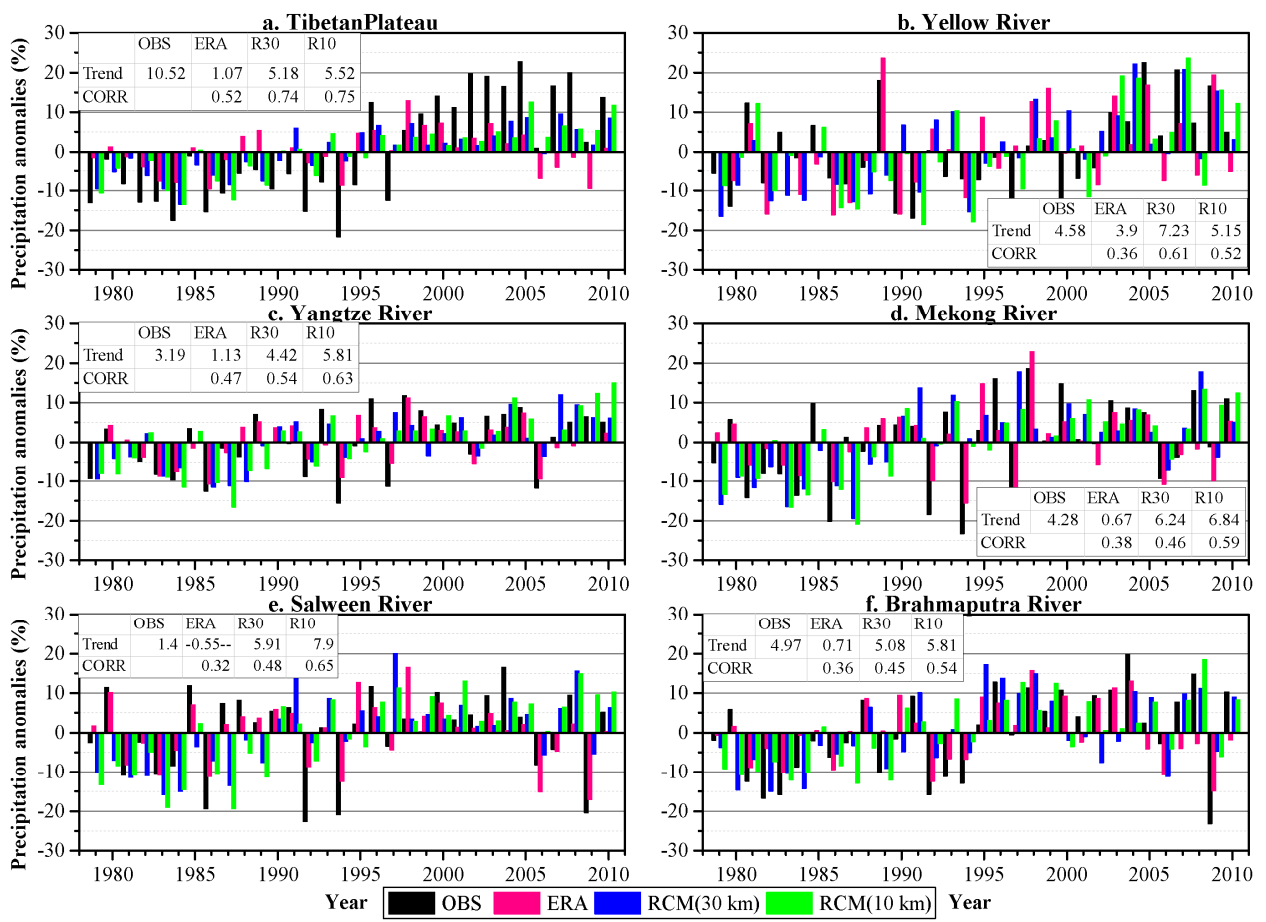

Figure 6. Same as Figure 5, but for precipitation (the unit of trend is \%/decade). The whole Tibetan Plateau (TP) (a) and five river basins (b-f) for the period 1980-2010. 


\subsection{Annual Cycle of Monthly Mean Temperature and Precipitation}

Figure 7 shows the annual cycle of simulated monthly mean temperature and precipitation from RegCM4 and observations for the entire TP and five subregions. It is found that the RegCM4 successfully reproduces the annual cycle of monthly mean temperature over the entire TP and most subregions. R30 underestimates the monthly mean temperature for the whole year in most regions, especially in winter and spring seasons when cold biases are close to $-4{ }^{\circ} \mathrm{C}$. In addition, the summer cold biases are substantially reduced when compared to other seasons. Compared with R30 simulations, the high-resolution simulation R10 displays a systematic warm bias of approximately $2{ }^{\circ} \mathrm{C}$, with the largest warm bias in summer. In other words, the cold biases were considerably reduced in the high-resolution R10 simulations, and even the warm biases were brought in summer. In all, better performance is detected in the annual cycle of simulated monthly mean temperature for R10 over the study area, except for the Yellow River basin where R30 already shows the almost perfect simulation.

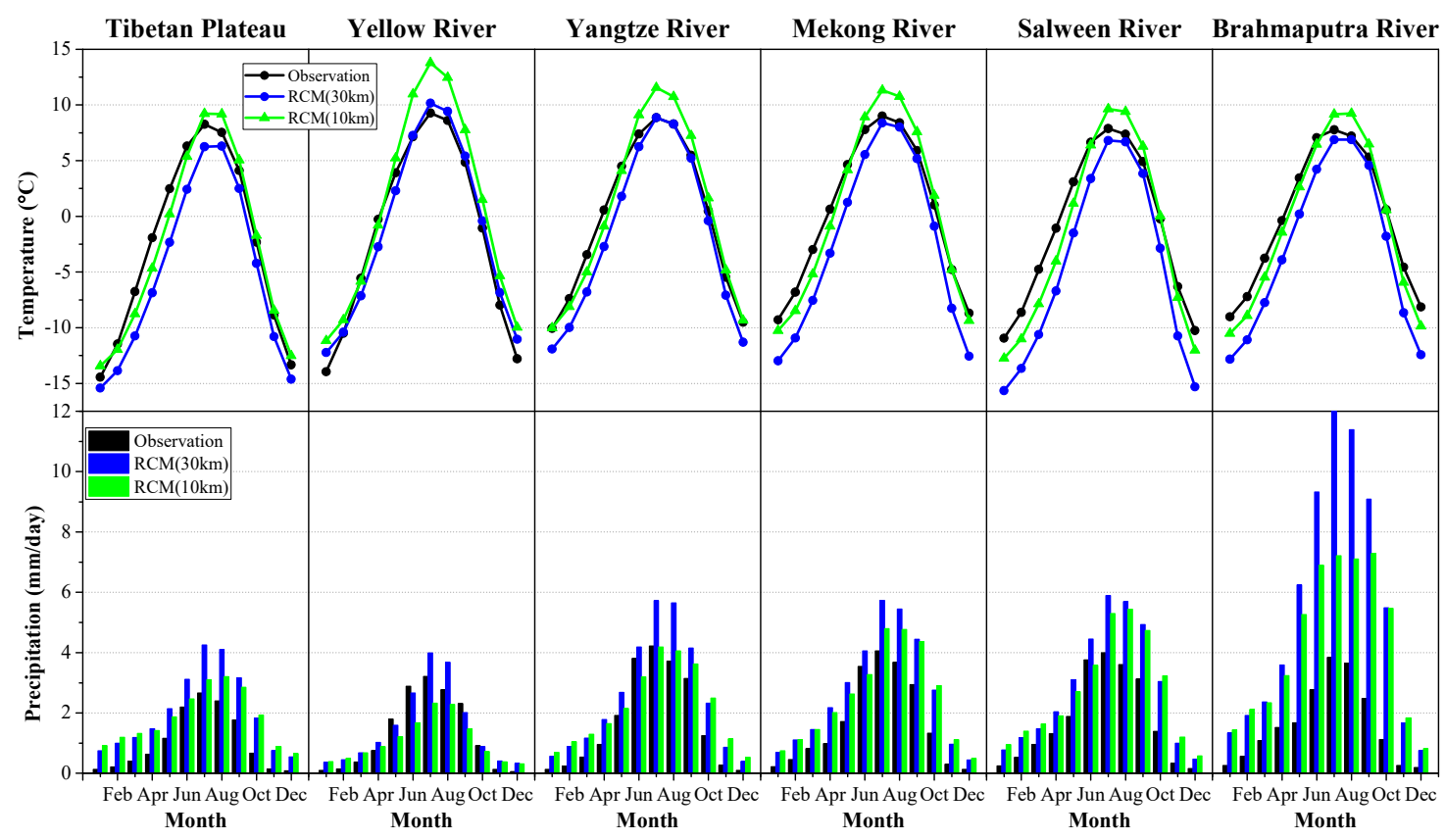

Figure 7. The comparison of observations with annual cycle of simulated monthly mean temperature and precipitation over TP and five river basins for the period 1980-2010.

Annual cycles of observed monthly precipitation are characterized by the bell-shape pattern with the maximum value in July due to the monsoon precipitation and the minimum value in December and January over the TP and five subregions, which can be captured well by the RegCM4 (Figure 7). This increases our confidence in the model to reproduce the main characteristics of precipitation regime, despite the model still having obvious biases in magnitude. The simulated basin-averaged precipitation from R30 is higher than the observations in most subregions throughout the year, particularly in the Brahmaputra River basin where the overestimation is above 50\% in summer, which is consistent with previous evaluations $[35,62]$. In contrary, the overestimation is mitigated by R10 where the representation of topographical influence on precipitation is improved at most regions, particularly for the Brahmaputra River basin where the significant seasonal precipitation overestimation from R30 occurs. Nevertheless, seasonal precipitation overestimation still exists in the simulation of R10 in the Brahmaputra River basin, which indicates that the $10-\mathrm{km}$ resolution is still not sufficient to describe the complex topographical features over the area along the Himalayas. 


\subsection{Daily Precipitation}

One of the major benefits of the RCMs is that they can provide smaller biases in extreme events simulations [63-65]. Figure 8 presents the simulated spatial distribution of five extreme precipitation indices and observations over the TP during the historical period 1980-2010. The intensity of the precipitation events is denoted by RX1DAY and SDII. Observed RX1DAY values of daily precipitation indicate that it is more extreme over most parts of the southeastern TP, and the largest values ( $>40 \mathrm{~mm} /$ day) are concentrated around $28 \mathrm{~N}$ along with small spots along the Himalayas. The observed RX1DAY is $18.6 \mathrm{~mm} /$ day averaged over the entire TP, and it ranges from 22.3 to $26.9 \mathrm{~mm} /$ day in five different basins (Table 3). Both R30 and R10 can reasonably capture the historical pattern of the mean annual RX1DAY. However, the R30 simulation greatly overestimates the yearly maximum daily precipitation, particularly in the Brahmaputra River basin where more than $200 \%$ overestimation was found. In contrary, the overestimation was greatly reduced in the R10 simulation; albeit, notably, overestimation still exists in the Brahmaputra River basin. In terms of the SDII, there is good agreement between the RegCM4 simulation and the observation over TP, as reflected by the percent biases being less than $20 \%$ in most regions. Similarly, SDII is overestimated in the R30 simulation over the Brahmaputra River basin, and the overestimation is reduced in R10 simulation.
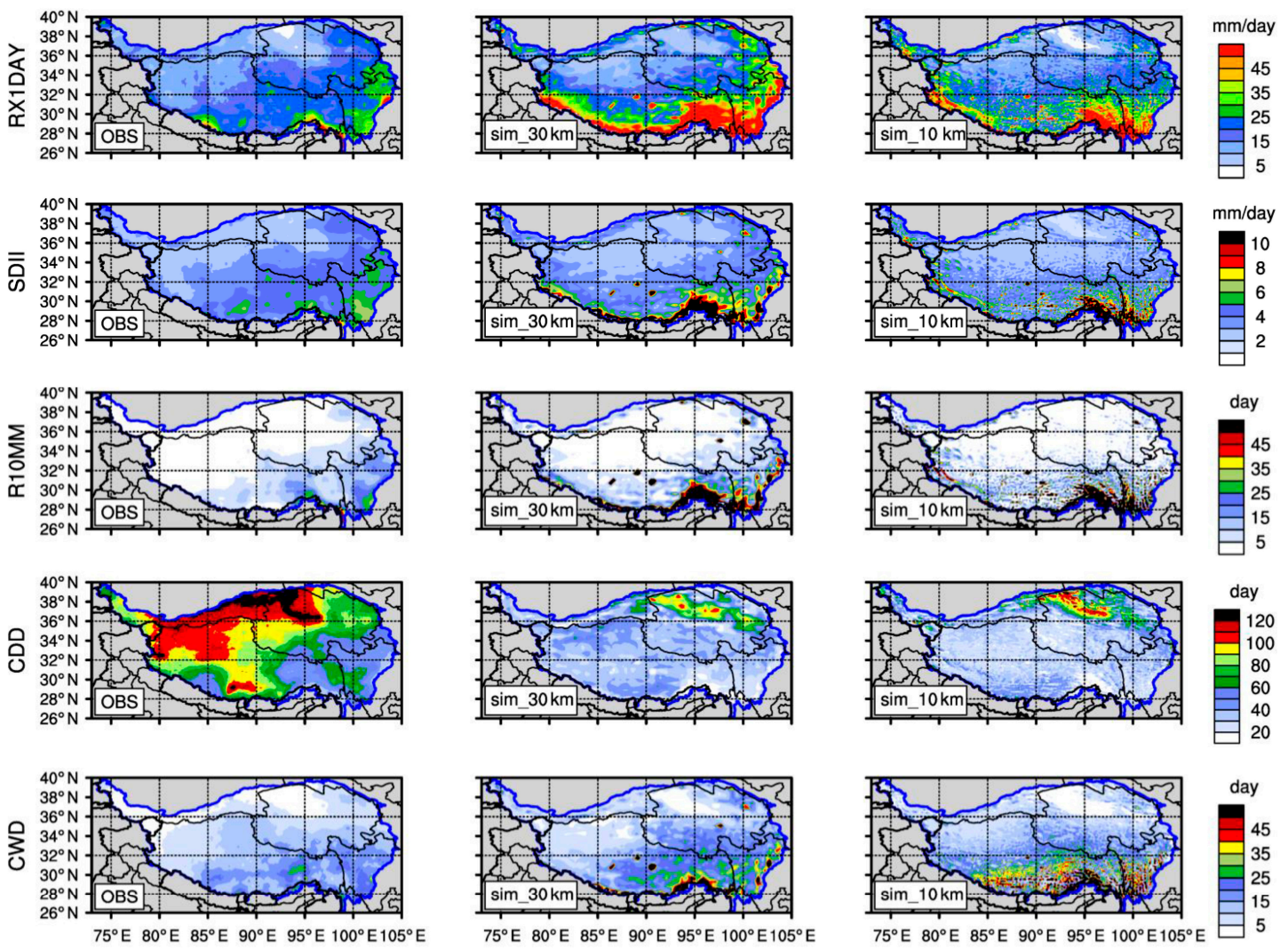

Figure 8. Spatial distribution of extreme precipitation indices based on the observation and two RegCM4 simulations over the TP (units: the former three in $\mathrm{mm} /$ day; the last two in day). 
Table 3. Observation and area averages of simulated extreme precipitation indicators for 1980-2010.

\begin{tabular}{|c|c|c|c|c|}
\hline & Index & OBS & R30 & R10 \\
\hline \multirow{5}{*}{$\mathrm{TP}$} & $\mathrm{R} 10 \mathrm{~mm}$ & 6.4 & 14.5 & 12.9 \\
\hline & RX1DAY & 18.6 & 32.9 & 25.5 \\
\hline & CWD & 11.0 & 16.8 & 18.4 \\
\hline & CDD & 81.5 & 38.6 & 36.9 \\
\hline & SDII & 3.7 & 4.6 & 4.1 \\
\hline \multirow{5}{*}{ Yellow river } & $\mathrm{R} 10 \mathrm{~mm}$ & 8.5 & 9.8 & 4.8 \\
\hline & RX1DAY & 22.3 & 27.5 & 19.0 \\
\hline & CWD & 10.2 & 15.0 & 10.9 \\
\hline & CDD & 65.7 & 47.2 & 43.4 \\
\hline & SDII & 4.4 & 4.1 & 3.3 \\
\hline \multirow{5}{*}{ Yangtze river } & $\mathrm{R} 10 \mathrm{~mm}$ & 13.0 & 20.8 & 17.1 \\
\hline & RX1DAY & 25.1 & 41.3 & 30.1 \\
\hline & CWD & 15.5 & 21.9 & 22.0 \\
\hline & CDD & 59.8 & 32.5 & 32.2 \\
\hline & SDII & 4.8 & 5.2 & 4.6 \\
\hline \multirow{5}{*}{ Mekong river } & $\mathrm{R} 10 \mathrm{~mm}$ & 12.3 & 21.5 & 19.8 \\
\hline & RX1DAY & 23.7 & 43.2 & 36.1 \\
\hline & CWD & 15.9 & 24.7 & 25.8 \\
\hline & CDD & 56.8 & 32.4 & 29.4 \\
\hline & SDII & 4.7 & 5.4 & 4.9 \\
\hline \multirow{5}{*}{ Salween river } & $\mathrm{R} 10 \mathrm{~mm}$ & 13.0 & 23.8 & 23.0 \\
\hline & RX1DAY & 24.5 & 48.5 & 37.9 \\
\hline & CWD & 17.2 & 24.1 & 28.3 \\
\hline & CDD & 53.4 & 31.3 & 27.9 \\
\hline & SDII & 4.7 & 5.8 & 5.3 \\
\hline \multirow{5}{*}{ Brahmaputra river } & $\mathrm{R} 10 \mathrm{~mm}$ & 12.0 & 44.3 & 38.9 \\
\hline & RX1DAY & 26.9 & 84.7 & 52.4 \\
\hline & CWD & 17.7 & 34.4 & 44.0 \\
\hline & CDD & 64.8 & 32.1 & 32.8 \\
\hline & SDII & 4.5 & 9.5 & 7.2 \\
\hline
\end{tabular}

R10mm stands for the frequency of precipitation events with daily precipitation amounts above $10 \mathrm{~mm}$. It is found that the observed $\mathrm{R} 10 \mathrm{~mm}$ reaches about 10 days over most regions. The simulated R10mm in R30 presented significant positive bias along the Himalayas. The largest bias for simulated R10mm from R30 occurring in the south of TP was greatly reduced in R10, despite only a small improvement being detected over other areas.

CDD and CWD are used for denoting the duration of dry/wet events. It is found that the observed consecutive dry days (CDD) is larger than 100 days over the severer arid region in the northwestern TP, whereas it is mostly less than 50 days in the southeastern TP (Figure 8). The Chaidam basin is recognized as the driest area with the observed highest $\mathrm{CDD}$. The second driest area is observed in the southwestern TP. Both R30 and R10 can capture the spatial distribution of CDD and identify the driest area (the Chaidam basin). However, two RegCM4 simulations underestimated the magnitude of CDD and cannot capture the second driest area located at the southwestern TP. In addition, the improvements in the accuracy of CDD modeling in higher-resolution simulation over most areas were marginal except for the Chaidam basin. The spatial pattern of observed CWD is opposite to that of the observed CDD. In addition, the simulated patterns for CWD from R10 and R30 show good agreement with observation, with an arid/semi-arid climate in northwestern TP and humid/semi-humid climate in southeastern TP. However, the magnitude of CWD was overestimated in both simulations, because I did not see a noticeable improvement from R30 to R10 in the TP.

It is important to investigate the added value of the high-resolution modeling in RegCM4 in terms of the distribution of daily precipitation frequency and amount. Figure 9 presents the frequency 
and accumulated amount for daily simulated area-averaged precipitation over the whole TP and five basins during 1980-2010. Generally, RegCM4 captures reasonably well the frequency and amount of daily precipitation events for different precipitation intensity classes in both R30 and R10 simulations. However, the model underestimates the number of dry days when the daily precipitation amount is smaller than $0.1 \mathrm{~mm} /$ day in all subregions, which can be partially attributed to the fact the model usually "drizzles" excessively when modeling the precipitation events with the lowest precipitation intensities, especially in the dry area $[66,67]$.

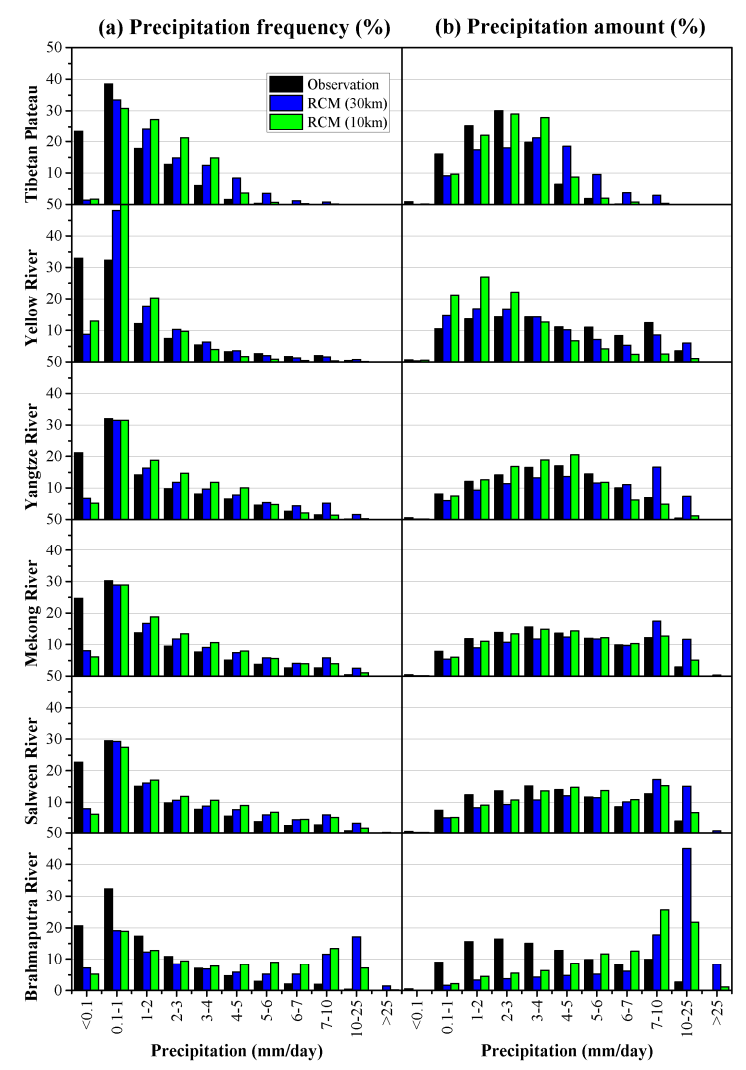

Figure 9. The distribution of frequency (a, left panel) and amount (b, right panel) for simulated daily area-averaged precipitation and observation over the whole TP and five basins (from top to bottom) during 1980-2010.

The frequency distribution of observed daily precipitation is featured by that higher precipitation intensity being accompanied by lower frequencies and the highest frequency occurred for the light precipitation event $(0.1-1 \mathrm{~mm} /$ day). It is clear that the observed light precipitation was well captured by the model in most areas, albeit the model overestimates it in the Yellow River basin and underestimates it in the Brahmaputra River basin. However, the simulated frequency of precipitation events where the daily precipitation intensity is above $1 \mathrm{~mm}$ /day is overestimated in the whole study area, with the highest overestimation existing in the frequency of relatively heavy precipitation (greater than $5 \mathrm{~mm} /$ day). The distribution for the precipitation amounts is similar among the TP and five subregions. A maximum occurring at an intensity of $2-3 \mathrm{~mm} /$ day is observed in the distribution of daily precipitation amount averaged over the TP, Yellow River (YE), and Brahmaputra River (BR). The results for the Yangtze River (YA), Mekong River (ME), and Salween River (SA) occur at higher intensity bins. These distribution patterns can be simulated well by the RegCM4. However, there is an underestimation in the amount of light and moderate precipitation and an overestimation of the amount of heavy precipitation in the $\mathrm{R} 30 \mathrm{~km}$. The overestimation of heavy precipitation events in R30 is improved by R10, indicating that a better accuracy was exhibited in higher resolution simulation. This is in line with previous studies 
from Zhang et al. [68] who suggest that the Emanuel scheme applied in the RegCM4 overestimates the convective activity and brings about excessively heavy precipitation in the RegCM4 model.

\subsection{Uncertainties}

In this section, the uncertainty in the model simulations is evaluated by means of the interannual variability methodology [69,70]. According to this approach, three categories of errors can be distinguished: overall errors identified by the location of the regression line above or below the diagonal, systematic errors in representing sensitivity quantified by the slope of the regression line, and unsystematic errors represented by the scatter of individual data points. Figure 10 shows scatterplots of observation and simulated annual mean temperature over the whole TP and five river basins for the period 1980-2010. Both R30 and R10 simulations show similar uncertainty in most areas of the TP. The overall errors are more than $-2{ }^{\circ} \mathrm{C}$ in $\mathrm{R} 30$ over most areas except for the Yellow River basin. This kind of error is reduced in R10 simulation over most areas. The regression lines for R30 and R10 simulations are parallel with each other, indicating a similar systematic bias in the representation of temperature sensitivity. Moreover, both simulations show a tendency toward an underestimation in different years. In addition, the uncertainty associated with unsystematic errors is also quite similar for R30 and R10, as is reflected by the similarity for the scatter degree of individual data points.
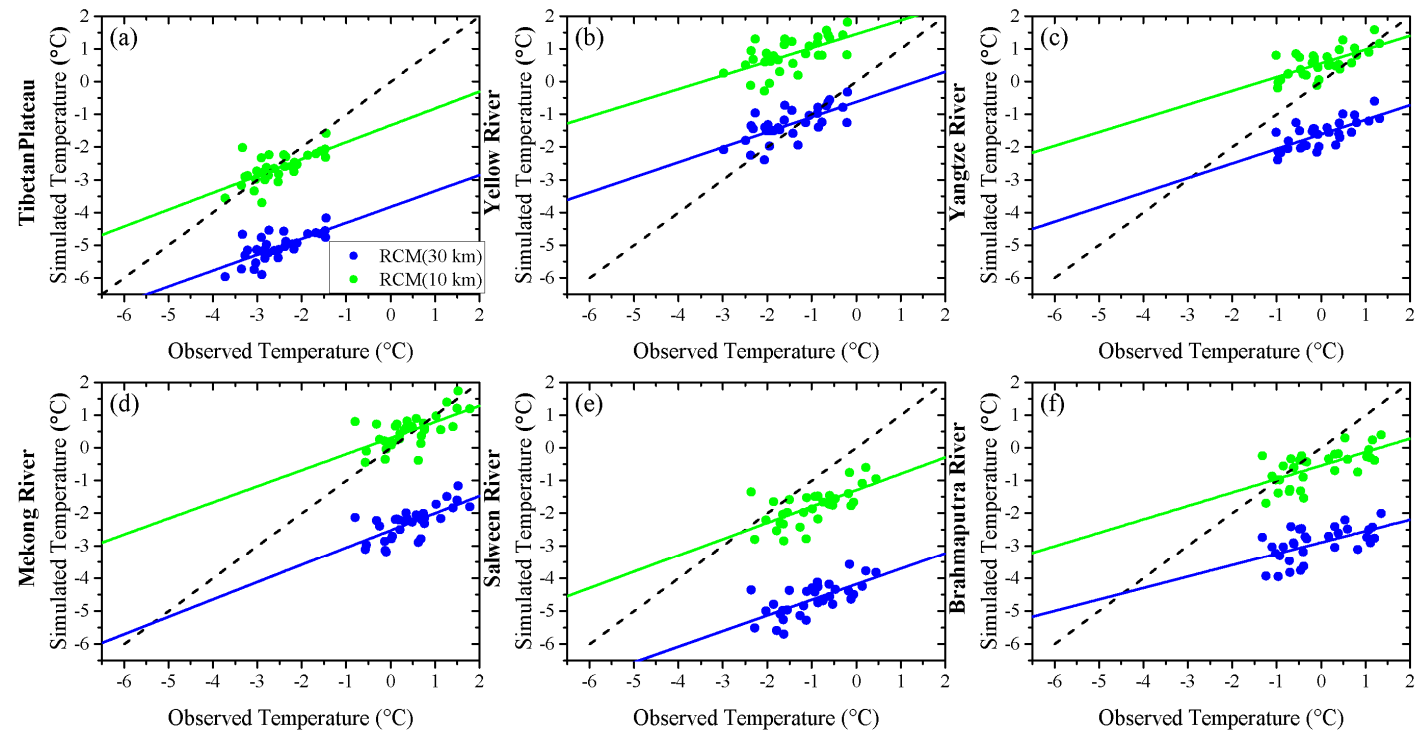

Figure 10. Scatterplots of observation and simulated annual mean temperature over the whole TP (a) and five river basins (from $\mathbf{b}$ to $\mathbf{f}$ ) and during the period 1980-2010. The diagonal black dashed line across the plot shows the perfect agreement.

The uncertainties in the RegCM4 precipitation simulations are much larger than those of air temperature (Figure 11). The results show that the precipitation is overestimated in the most of the subregions. The overall error is substantially reduced in the higher-resolution simulation R10 over the entire TP and most subregions, albeit the overestimation of the precipitation systematic and unsystematic errors is only marginally improved. 

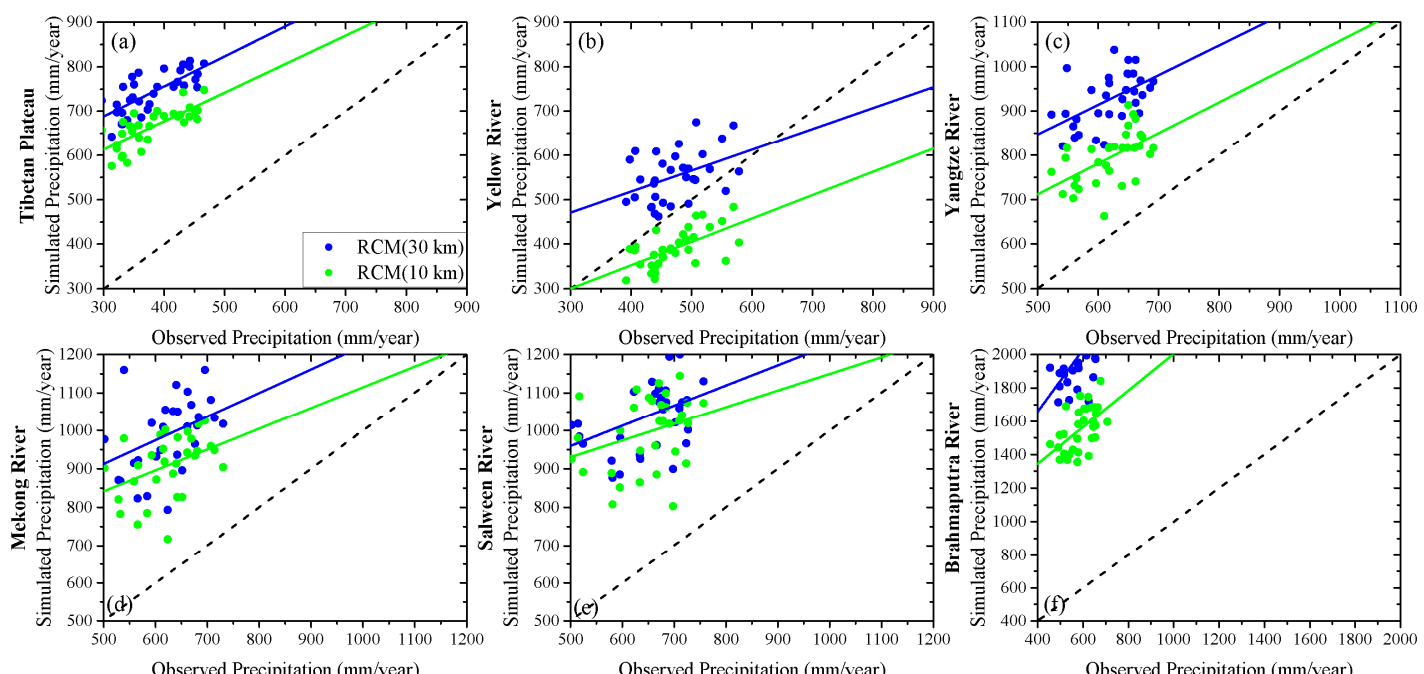

Figure 11. Same as Figure 10, but for precipitation. The whole TP (a) and five river basins (from $\mathbf{b}$ to $\mathbf{f}$ ) and during the period 1980-2010.

\section{Discussion}

The cold biases in RegCM4 simulations are found in large parts of the TP, especially in the western TP, which are consistent with the results reported by Ji et al. [42], Wang, et al. [43], Gao et al. [71], and Khandu et al. [72], who used other RCMs to investigate the major regional climate features during the historical period over the TP. The temperature biases are likely caused by the imperfect description of physical processes in the regional climate model and the biases in the boundary forcing data. Wang and Zeng [73] indicated that the surface air temperature of the ERA-Interim is underestimated over the TP and suggested that elevation differences between the grid cell and stations largely accounted for the cold bias caused by the low density of meteorological stations. Gao et al. [71] reported in their study that the cold bias could largely be reduced when using a lapse rate correction method based on the difference between station and model elevations.

The RegCM4 simulations overestimate the seasonal precipitation in most of the modeling area. It seems to be common that the wet bias for precipitation in the areas with complex topography is shown in several RCMs simulations [71,74-76]. This is likely concerned with the drawbacks of the models in that they overestimate orographic precipitation enhancement [77] and/or have poor performance in the simulation of the planetary boundary layer [78]. In addition, the ERA-Interim driving data have a wet bias in precipitable water [79], which can also lead to the overestimation of precipitation over the TP $[80,81]$.

RCM simulation performance over long time scales is known to be linked to the quality of the lateral boundary conditions supplied to the model. Bias correction of the ERA-Interim reanalysis dataset would lead to better skill and consistent downscaled results [82]. However, it is still difficult to correct the bias of ERA-Interim reanalysis over the TP for the following reasons: (1) the ground-based observation is the only available meteorological data over the TP, and the data such as wind speed, temperature, geopotential height, and specific humidity at different heights above ground are absent; (2) part of the ground-based observation over the TP has been merged in the ERA-Interim reanalysis dataset; and (3) satellite data are considered as a promising choice to correct the ERA-Interim reanalysis datasets [83]. However, these data usually begin at the end of the 20th century or the beginning of the 21st century, which cannot cover the time span applied in this study.

\section{Conclusions}

In this study, we evaluate and compare the ability of the RegCM4 model with two horizontal resolutions in reproducing the major regional climate features for the period from 1980 to 2010 over the 
TP and five subregions, which are the most sensitive area of climate change in China with extremely complex topography. The simulations are driven by the ERA-Interim reanalysis datasets. A novel daily observational dataset is employed as reference data to evaluate the performance of the RegCM4. The main findings are shown as follows:

(1) Both RegCM4 simulations could capture the spatial pattern of seasonal air temperature well. Moreover, better performance is obtained in the R10 run in comparison with the R30 run, as reflected by higher spatial correlations (ranging from 0.82 to 0.91 ), lower bias, and lower RMSE error between the R10 run simulations and observation in all seasons. In addition, the cold bias of the area-averaged air temperature in R30 is greatly reduced by R10.

(2) The RegCM4 simulations overestimate the seasonal precipitation in most of the modeling area. Wet biases for summer precipitation from R30 are obviously reduced in R10. However, there is no clear evidence to show an improvement in spatial pattern of seasonal precipitation for the higherresolution simulation.

(3) The substantial warming trends in the domain were well captured by the RegCM4 simulations, although it was underestimated because of the limitations in the reanalysis boundary forcing data. By contrast, the slight wetting trends simulated by both RegCM4 simulations show significant improvement compared to the results from the driving data. In addition, RegCM4 is able to capture the annual cycle of monthly mean temperature and precipitation over all regions. R10 is able to mitigate the positive bias of monthly mean precipitation at most regions, particularly for the summer precipitation in the Brahmaputra River basin. This is attributed to the representation of the topographical influence on precipitation in R10.

(4) The spatial distributions of extreme precipitation were also captured reasonably in RegCM4 simulations. The added value of higher resolution is reflected in smaller wet biases in extreme precipitation statistics, suggesting that the higher resolution simulation is conducive to reduce the uncertainty in modeling the detail of local heavy precipitation events associated with mesoscale convection, especially in the complex terrain area. This is in line with findings by Maussion [84].

In short, the findings in this work indicate that $\mathrm{RegCM} 4$ can reproduce the major regional climate features, but substantial uncertainties still exist, especially in the Brahmaputra River basin. This is probably related to the fact that a horizontal resolution of $10 \mathrm{~km}$ used in our experiments is not fine enough to resolve the topoclimates over the complex Himalayan terrain in the Brahmaputra River basin $[38,85,86]$. In addition, the good performance of the RegCM4 simulations justify that it can be applied as a high-resolution climate dataset for impact models such as the hydrological model, and its potential to study the changes in glacier, river streamflow, and snowpack dynamics over the TP under the context of climate change.

Author Contributions: H.G. designed and carried out this research. H.G. wrote this paper. X.W. prepared and analyzed the data. All authors have read and agreed to the published version of the manuscript.

Funding: This work was supported by the National Key R\&D Program of China (No. 2016YFC0402706, 2016YFC0402710), the National Natural Science Foundation of China (No. 51539003, 41761134090, 41807149, 51709074), and the Fundamental Research Funds for the Central Universities (2019B10614).

Acknowledgments: The observation dataset used in this study was developed by Data Assimilation and Modeling Center for Tibetan Multi-spheres, Institute of Tibetan Plateau Research, Chinese Academy of Sciences.

Conflicts of Interest: The authors declare no conflict of interest.

\section{References}

1. Qiu, J. China: The Third Pole. Nat. Cell Biol. 2008, 454, 393-396. [CrossRef]

2. Yao, T.; Xue, Y.; Chen, D.; Chen, F.; Thompson, L.; Cui, P.; Koike, T.; Lau, W.K.-M.; Lettenmaier, D.; Mosbrugger, V.; et al. Recent Third Pole's Rapid Warming Accompanies Cryospheric Melt and Water Cycle Intensification and Interactions between Monsoon and Environment: Multidisciplinary Approach with Observations, Modeling, and Analysis. Bull. Am. Meteorol. Soc. 2019, 100, 423-444. [CrossRef] 
3. Duan, A.M.; Wu, G. Role of the Tibetan Plateau Thermal Forcing in the Summer Climate Patterns Over Subtropical Asia. Clim. Dyn. 2005, 24, 793-807. [CrossRef]

4. Yao, T.; Thompson, L.; Yang, W.; Yu, W.; Gao, Y.; Guo, X.; Yang, X.; Duan, K.; Zhao, H.; Xu, B.; et al. Different glacier status with atmospheric circulations in Tibetan Plateau and surroundings. Nat. Clim. Chang. 2012, 2, 663-667. [CrossRef]

5. Immerzeel, W.W.; Van Beek, L.P.H.; Bierkens, M.F.P. Climate Change Will Affect the Asian Water Towers. Science 2010, 328, 1382-1385. [CrossRef] [PubMed]

6. Wu, S.; Yin, Y.; Zheng, D.; Yang, Q. Climatic Trends Over the Tibetan Plateau During 1971-2000. J. Geogr. Sci. 2007, 17, 141-151. [CrossRef]

7. Zhang, D.; Huang, J.; Guan, X.; Chen, B.; Zhang, L. Long-Term Trends of Precipitable Water and Precipitation Over the Tibetan Plateau Derived from Satellite and Surface Measurements. J. Quant. Spectrosc. Radiat. Transf. 2013, 122, 64-71. [CrossRef]

8. You, Q.; Kang, S.; Aguilar, E.; Yan, Y. Changes in daily climate extremes in the eastern and central Tibetan Plateau during 1961-2005. J. Geophys. Res. Space Phys. 2008, 113, 113. [CrossRef]

9. You, Q.; Kang, S.; Wu, Y.; Yan, Y. Climate Change Over the Yarlung Zangbo River Basin during 1961-2005. J. Geogr. Sci. 2007, 17, 409-420. [CrossRef]

10. Bibi, S.; Wang, L.; Li, X.; Zhou, J.; Chen, D.; Yao, T. Climatic and Associated Cryospheric, Biospheric, and Hydrological Changes on the Tibetan Plateau: A Review. Int. J. Clim. 2018, 38, e1-e17. [CrossRef]

11. Biemans, H.; Siderius, C.; Lutz, A.F.; Nepal, S.; Ahmad, B.; Hassan, S.M.T.; Von Bloh, W.; Wijngaard, R.R.; Wester, P.; Shrestha, A.B.; et al. Importance of Snow and Glacier Meltwater for Agriculture on the Indo-Gangetic Plain. Nat. Sustain. 2019, 2, 594-601. [CrossRef]

12. Klein, J.A.; Hopping, K.A.; Yeh, E.T.; Nyima, Y.; Boone, R.B.; Galvin, K.A. Unexpected Climate Impacts on the Tibetan Plateau: Local and Scientific Knowledge in Findings of Delayed Summer. Glob. Environ. Chang. 2014, 28, 141-152. [CrossRef]

13. Cuo, L.; Zhang, Y.; Wang, Q.; Zhang, L.; Zhou, B.; Hao, Z.; Su, F. Climate Change on the Northern Tibetan Plateau during 1957-2009: Spatial Patterns and Possible Mechanisms. J. Clim. 2013, 26, 85-109. [CrossRef]

14. Maurer, J.M.; Schaefer, J.M.; Rupper, S.; Corley, A. Acceleration of Ice Loss Across the Himalayas Over the Past 40 Years. Sci. Adv. 2019, 5, eaav7266. [CrossRef]

15. Li, B.; Yu, Z.; Liang, Z.; Acharya, K. Hydrologic Response of a High Altitude Glacierized Basin in the Central Tibetan Plateau. Glob. Planet Chang. 2014, 118, 69-84. [CrossRef]

16. Li, B.; Zhang, J.; Yu, Z.; Liang, Z.; Chen, L.; Acharya, K. Climate Change Driven Water Budget Dynamics of a Tibetan Inland Lake. Glob. Planet Chang. 2017, 150, 70-80. [CrossRef]

17. Gu, H.; Yu, Z.; Wang, J.; Wang, G.; Yang, T.; Ju, Q.; Yang, C.; Xu, F.; Fan, C. Assessing CMIP5 General Circulation Model Simulations of Precipitation and Temperature Over China. Int. J. Climatol. 2014, 35, 2431-2440. [CrossRef]

18. Gu, H.; Yu, Z.; Yang, C.; Ju, Q.; Yang, T.; Zhang, D. High-Resolution Ensemble Projections and Uncertainty Assessment of Regional Climate Change Over China in CORDEX East Asia. Hydrol. Earth Syst. Sci. 2018, 22, 3087-3103. [CrossRef]

19. Su, F.; Duan, X.; Chen, D.; Hao, Z.; Cuo, L. Evaluation of the Global Climate Models in the CMIP5 over the Tibetan Plateau. J. Clim. 2013, 26, 3187-3208. [CrossRef]

20. Wei, Z.; Dong, W. Assessment of Simulations of Snow Depth in the Qinghai-Tibetan Plateau Using CMIP5 Multi-Models. Arct. Antarct. Alp. Res. 2015, 47, 611-625. [CrossRef]

21. Gu, H.; Wang, G.; Yu, Z.; Mei, R. Assessing Future Climate Changes and Extreme Indicators in East and South Asia Using the RegCM4 Regional Climate Model. Clim. Chang. 2012, 114, 301-317. [CrossRef]

22. Xu, J.; Koldunov, N.V.; Remedio, A.R.; Sein, D.; Zhi, X.; Jiang, X.; Xu, M.; Zhu, X.; Fraedrich, K.; Jacob, D. On the Role of Horizontal Resolution Over the Tibetan Plateau in the REMO Regional Climate Model. Clim. Dyn. 2018, 51, 4525-4542. [CrossRef]

23. Gao, Y.; Xiao, L.; Chen, D.; Xu, J.; Zhang, H. Comparison Between Past and Future Extreme Precipitations Simulated by Global and Regional Climate Models Over the Tibetan Plateau. Int. J. Climatol. 2017, 38, 1285-1297. [CrossRef]

24. Sato, T.; Yoshikane, T.; Satoh, M.; Miura, H.; Fujinami, H. Resolution Dependency of the Diurnal Cycle of Convective Clouds over the Tibetan Plateau in a Mesoscale Model. J. Meteorol. Soc. Jpn. 2008, 86, 17-31. [CrossRef] 
25. Gao, X.-J.; Shi, Y.; Giorgi, F. Comparison of Convective Parameterizations in RegCM4 Experiments Over China with CLM as the Land Surface Model. Atmos. Ocean. Sci. Lett. 2016, 9, 246-254. [CrossRef]

26. Gao, Y.; Xiao, L.; Chen, D.; Chen, F.; Xu, J.; Xu, Y. Quantification of the Relative Role of Land-Surface Processes and Large-Scale Forcing in Dynamic Downscaling Over the Tibetan Plateau. Clim. Dyn. 2016, 48, 1705-1721. [CrossRef]

27. Wang, X.; Pang, G.; Yang, M.; Zhao, G. Evaluation of Climate on the Tibetan Plateau Using ERA-Interim Reanalysis and Gridded Observations during the Period 1979-2012. Quat. Int. 2017, 444, 76-86. [CrossRef]

28. Gao, Y.; Li, K.; Chen, F.; Jiang, Y.; Lu, C. Assessing and Improving Noah-MP Land Model Simulations for the Central Tibetan Plateau. J. Geophys. Res. Atmos. 2015, 120, 9258-9278. [CrossRef]

29. Wang, X.; Yang, M.; Pang, G. Sensitivity of Regional Climate Simulations to Land-Surface Schemes on the Tibetan Plateau. Clim. Res. 2014, 62, 25-43. [CrossRef]

30. Wang, X.; Yang, T.; Wortmann, M.; Shi, P.; Hattermann, F.; Lobanova, A.; Aich, V. Analysis of MultiDimensional Hydrological Alterations Under Climate Change for Four Major River Basins in Different Climate Zones. Clim. Chang. 2016, 141, 483-498. [CrossRef]

31. Wang, X.; Yang, T.; Xu, C.-Y.; Gourley, J.J.; Shi, P. Understanding the Discharge Regime of a Glacierized Alpine Catchment in the Tianshan Mountains Using an Improved HBV-D Hydrological Model. Glob. Planet Chang. 2019, 172, 211-222. [CrossRef]

32. Ge, G.; Shi, Z.; Yang, X.H.; Hao, Y.; Guo, H.; Kossi, F.; Xin, Z.; Wei, W.; Zhang, Z.; Zhang, X.; et al. Analysis of Precipitation Extremes in the Qinghai-Tibetan Plateau, China: Spatio-Temporal Characteristics and Topography Effects. Atmosphere 2017, 8, 127. [CrossRef]

33. Nepal, S.; Shrestha, A.B. Impact of Climate Change on the Hydrological Regime of the Indus, Ganges and Brahmaputra River Basins: A Review of the Literature. Int. J. Water Resour. Dev. 2015, 31, 201-218. [CrossRef]

34. Lutz, A.F.; Immerzeel, W.W.; Shrestha, A.B.; Bierkens, M.F.P. Consistent Increase in High Asia's Runoff Due to Increasing Glacier Melt and Precipitation. Nat. Clim. Chang. 2014, 4, 587-592. [CrossRef]

35. Gu, H.; Yu, Z.; Peltier, W.R.; Wang, X. Studies and Comprehensive Evaluation of RegCM4.6.1 High-Resolution Climate Simulations Over the Tibetan Plateau. Clim. Dyn. 2020, 54, 3781-3801. [CrossRef]

36. Oh, S.-G.; Park, J.-H.; Lee, S.-H.; Suh, M.-S. Assessment of the RegCM4 over East Asia and Future Precipitation Change Adapted to the RCP Scenarios. J. Geophys. Res. Atmos. 2014, 119, 2913-2927. [CrossRef]

37. Pal, J.S.; Giorgi, F.; Bi, X.; Elguindi, N.; Solmon, F.; Gao, X.; Rauscher, S.A.; Francisco, R.; Zakey, A.; Winter, J.; et al. Regional Climate Modeling for the Developing World: The ICTP RegCM3 and RegCNET. Bull. Am. Meteorol. Soc. 2007, 88, 1395-1410. [CrossRef]

38. Gao, X.; Giorgi, F. Use of the RegCM System over East Asia: Review and Perspectives. Engineering 2017, 3, 766-772. [CrossRef]

39. Gao, X.; Ying, S.; Giorgi, F. A High Resolution Simulation of Climate Change Over China. Sci. China Earth Sci. 2010, 54, 462-472. [CrossRef]

40. Kang, S.; Im, E.-S.; Ahn, J.-B. The Impact of Two Land-Surface Schemes on the Characteristics of Summer Precipitation Over East Asia From the RegCM4 Simulations. Int. J. Climatol. 2014, 34, 3986-3997. [CrossRef]

41. Shi, Y.; Wang, G.; Gao, X. Role of Resolution in Regional Climate Change Projections Over China. Clim. Dyn. 2017, 51, 2375-2396. [CrossRef]

42. Ji, Z.; Kang, S. Double-Nested Dynamical Downscaling Experiments over the Tibetan Plateau and Their Projection of Climate Change under Two RCP Scenarios. J. Atmos. Sci. 2013, 70, 1278-1290. [CrossRef]

43. Wang, X.; Pang, G.; Yang, M.; Wan, G. Effects of Modified Soil Water-Heat Physics on RegCM4 Simulations of Climate Over the Tibetan Plateau. J. Geophys. Res. Atmos. 2016, 121, 6692-6712. [CrossRef]

44. Giorgi, F.; Jones, C.; Asrar, G.R. Addressing Climate Information Needs at the Regional Level: The CORDEX Framework. WMO Bull. 2009, 58, 175-183.

45. Kiehl, J.T.; Hack, J.J.; Bonan, G.B.; Boville, B.A.; Breigleb, B.P.; Williamson, D.; Rasch, P. Description of the Ncar Community Climate Model CCM3; National Center for Atmospheric Research: Boulder, CO, USA, 1996.

46. Holtslag, A.A.M.; Boville, B.A. Local Versus Nonlocal Boundary-Layer Diffusion in a Global Climate Model. J. Clim. 1993, 6, 1825-1842. [CrossRef]

47. Emanuel, K.A. A Scheme for Representing Cumulus Convection in Large-Scale Models. J. Atmos. Sci. 1991, 48, 2313-2329. [CrossRef]

48. Zeng, X.; Zhao, M.; Dickinson, R.E. Intercomparison of Bulk Aerodynamic Algorithms for the Computation of Sea Surface Fluxes Using TOGA COARE and TAO Data. J. Clim. 1998, 11, 2628-2644. [CrossRef] 
49. Oleson, K.W.; Niu, G.-Y.; Yang, Z.-L.; Lawrence, D.; Thornton, P.; Lawrence, P.J.; Stöckli, R.; Dickinson, R.E.; Bonan, G.B.; Levis, S.; et al. Improvements to the Community Land Model and Their Impact on the Hydrological Cycle. J. Geophys. Res. Space Phys. 2008, 113. [CrossRef]

50. Feng, L.; Zhou, T. Water Vapor Transport for Summer Precipitation Over the Tibetan Plateau: Multidata Set Analysis. J. Geophys. Res. Space Phys. 2012, 117. [CrossRef]

51. Tian, L.; Yao, T.; MacClune, K.; White, J.W.C.; Schilla, A.; Vaughn, B.; Vachon, R.; Ichiyanagi, K. Stable Isotopic Variations in West China: A Consideration of Moisture Sources. J. Geophys. Res. Space Phys. 2007, 112, 112. [CrossRef]

52. Zhang, Y.; Li, J. Impact of Moisture Divergence on Systematic Errors in Precipitation Around the Tibetan Plateau in a General Circulation Model. Clim. Dyn. 2016, 47, 2923-2934. [CrossRef]

53. Dee, D.P.; Uppala, S.M.; Simmons, A.J.; Berrisford, P.; Poli, P.; Kobayashi, S.; Andrae, U.; Balmaseda, M.A.; Balsamo, G.; Bauer, P.; et al. The ERA-Interim reanalysis: Configuration and performance of the data assimilation system. Q. J. R. Meteorol. Soc. 2011, 137, 553-597. [CrossRef]

54. Bao, X.; Zhang, F. Evaluation of NCEP-CFSR, NCEP-NCAR, ERA-Interim, and ERA-40 Reanalysis Datasets against Independent Sounding Observations over the Tibetan Plateau. J. Clim. 2013, 26, 206-214. [CrossRef]

55. Brands, S.; Herrera, S.; Fernández, J.; Gutiérrez, J.M. How Well Do CMIP5 Earth System Models Simulate Present Climate Conditions in Europe and Africa? Clim. Dyn. 2013, 41, 803-817. [CrossRef]

56. Reynolds, R.W.; Rayner, N.A.; Smith, T.M.; Stokes, D.C.; Wang, W. An Improved in Situ and Satellite SST Analysis for Climate. J. Clim. 2002, 15, 1609-1625. [CrossRef]

57. He, J.; Yang, K.; Tang, W.; Lu, H.; Qin, J.; Chen, Y.; Li, X. The First High-Resolution Meteorological Forcing Dataset for Land Process Studies Over China. Sci. Data 2020, 7, 25. [CrossRef]

58. Chen, Y.; Yang, K.; He, J.; Qin, J.; Shi, J.; Du, J.; He, Q. Improving Land Surface Temperature Modeling for Dry Land of China. J. Geophys. Res. Space Phys. 2011, 116. [CrossRef]

59. Yang, K.; He, J.; Tang, W.; Qin, J.; Cheng, C.C. On Downward Shortwave and Longwave Radiations Over High Altitude Regions: Observation and Modeling in the Tibetan Plateau. Agric. For. Meteorol. 2010, 150, 38-46. [CrossRef]

60. Sillmann, J.; Kharin, V.V.; Zhang, X.; Zwiers, F.W.; Bronaugh, D. Climate Extremes Indices in the CMIP5 Multimodel Ensemble: Part 1. Model Evaluation in the Present Climate. J. Geophys. Res. Atmos. 2013, 118, 1716-1733. [CrossRef]

61. Taylor, K.E. Summarizing Multiple Aspects of Model Performance in a Single Diagram. J. Geophys. Res. Space Phys. 2001, 106, 7183-7192. [CrossRef]

62. Lin, C.; Chen, D.; Yang, K.; Ou, T. Impact of Model Resolution on Simulating the Water Vapor Transport through the Central Himalayas: Implication for Models' Wet Bias Over the Tibetan Plateau. Clim. Dyn. 2018, 51, 3195-3207. [CrossRef]

63. Beniston, M.; Stephenson, D.B.; Christensen, O.B.; Ferro, C.A.T.; Frei, C.; Goyette, S.; Halsnaes, K.; Holt, T.; Jylhä, K.; Koffi, B.; et al. Future Extreme Events in European Climate: An Exploration of Regional Climate Model Projections. Clim. Chang. 2007, 81, 71-95. [CrossRef]

64. Dominguez, M.; Romera, R.; Sánchez, E.; Fita, L.; Cardoso, R.M.; Jimenez-Guerrero, P.; Montavez, J.P.; Cabos, W.; Liguori, G.; Gaertner, M. Present-Climate Precipitation and Temperature Extremes Over Spain From a Set of High Resolution RCMs. Clim. Res. 2013, 58, 149-164. [CrossRef]

65. Gu, H.; Yu, Z.; Yang, C.; Ju, Q. Projected Changes in Hydrological Extremes in the Yangtze River Basin with an Ensemble of Regional Climate Simulations. Water 2018, 10, 1279. [CrossRef]

66. Halenka, T.; Kalvová, J.; Chládová, Z.; Demeterová, A.; Zemánková, K.; Belda, M. On the Capability of RegCM to Capture Extremes in Long Term Regional Climate Simulation-Comparison with the Observations for Czech Republic. Theor. Appl. Climatol. 2006, 86, 125-145. [CrossRef]

67. Seth, A.; Rojas, M.; Liebmann, B.; Qian, J. Daily Rainfall Analysis for South America From a Regional Climate Model and Station Observations. Geophys. Res. Lett. 2004, 31. [CrossRef]

68. Zhang, S.; Lu, S.; Bao, Y.; Ma, D. Sensitivity of Precipitation Over China to Different Cumulus Parameterization Schemes in RegCM4. J. Meteorol. Res. 2015, 29, 119-131. [CrossRef]

69. Lüthi, D.; Cress, A.; Davies, H.C.; Frei, C.; Schär, C. Interannual Variability and Regional Climate Simulations. Theor. Appl. Climatol. 1996, 53, 185-209. [CrossRef]

70. Vidale, P.L. Predictability and Uncertainty in a Regional Climate Model. J. Geophys. Res. Space Phys. 2003, 108, 4586. [CrossRef] 
71. Gao, Y.; Xu, J.; Chen, D. Evaluation of WRF Mesoscale Climate Simulations Over the Tibetan Plateau during 1979-2011. J. Clim. 2015, 28, 2823-2841. [CrossRef]

72. Khandu; Awange, J.; Anyah, R.; Kuhn, M.; Fukuda, Y. Assessing Regional Climate Simulations of the Last 30 Years (1982-2012) Over Ganges-Brahmaputra-Meghna River Basin. Clim. Dyn. 2016, 49, 2329-2350. [CrossRef]

73. Wang, A.; Zeng, X. Evaluation of Multireanalysis Products with In Situ Observations Over the Tibetan Plateau. J. Geophys. Res. Space Phys. 2012, 117. [CrossRef]

74. Feng, J.; Fu, C. Inter-Comparison of 10-Year Precipitation Simulated by Several RCMs for Asia. Adv. Atmos. Sci. 2006, 23, 531-542. [CrossRef]

75. Guo, D.; Sun, J.; Yu, E.-T. Evaluation of CORDEX Regional Climate Models in Simulating Temperature and Precipitation Over the Tibetan Plateau. Atmos. Ocean. Sci. Lett. 2018, 11, 219-227. [CrossRef]

76. Jiang, X.; Wu, Y.; Li, Y.; Shu, J. Simulation of Interannual Variability of Summer Rainfall Over the Tibetan Plateau by the Weather Research and Forecasting Model. Int. J. Climatol. 2018, 39, 756-767. [CrossRef]

77. Gerber, F.; Besic, N.; Sharma, V.; Mott, R.; Daniels, M.; Gabella, M.; Berne, A.; Germann, U.; Lehning, M. Spatial Variability in Snow Precipitation and Accumulation in COSMO-WRF Simulations and Radar Estimations Over Complex Terrain. Cryosphere 2018, 12, 3137-3160. [CrossRef]

78. Russo, E.; Kirchner, I.; Pfahl, S.; Schaap, M.; Cubasch, U. Sensitivity Studies with the Regional Climate Model COSMO-CLM 5.0 over the CORDEX Central Asia Domain. Geosci. Model Dev. 2019, 12, 5229-5249. [CrossRef]

79. Wang, S.; Sobel, A.H.; Zhang, F.; Sun, Y.Q.; Yue, Y.; Zhou, L. Regional Simulation of the October and November MJO Events Observed during the CINDY/DYNAMO Field Campaign at Gray Zone Resolution. J. Clim. 2015, 28, 2097-2119. [CrossRef]

80. Huang, D.; Gao, S. Impact of Different Reanalysis Data on WRF Dynamical Downscaling over China. Atmos. Res. 2018, 200, 25-35. [CrossRef]

81. Zhang, Q.; Pan, Y.; Wang, S.; Xu, J.; Tang, J. High-Resolution Regional Reanalysis in China: Evaluation of 1 Year Period Experiments. J. Geophys. Res. Atmos. 2017, 122, 10-801. [CrossRef]

82. Kanamaru, H.; Kanamitsu, M. Scale-Selective Bias Correction in a Downscaling of Global Analysis Using a Regional Model. Mon. Weather Rev. 2007, 135, 334-350. [CrossRef]

83. Moalafhi, D.B.; Sharma, A.; Evans, J.P.; Mehrotra, R.; Rocheta, E. Impact of Bias-Corrected Reanalysis-Derived Lateral Boundary Conditions on WRF Simulations. J. Adv. Model Earth Syst. 2017, 9, 1828-1846. [CrossRef]

84. Maussion, F.; Scherer, D.; Mölg, T.; Collier, E.; Curio, J.; Finkelnburg, R. Precipitation Seasonality and Variability over the Tibetan Plateau as Resolved by the High Asia Reanalysis. J. Clim. 2014, 27, 1910-1927. [CrossRef]

85. Hasson, S.U. Seasonality of Precipitation over Himalayan Watersheds in CORDEX South Asia and their Driving CMIP5 Experiments. Atmosphere 2016, 7, 123. [CrossRef]

86. Hasson, S.U.; Böhner, J.; Chishtie, F. Low Fidelity of CORDEX and Their Driving Experiments Indicates Future Climatic Uncertainty Over Himalayan Watersheds of Indus Basin. Clim. Dyn. 2018, 52, 777-798. [CrossRef]

Publisher's Note: MDPI stays neutral with regard to jurisdictional claims in published maps and institutional affiliations.

(C) 2020 by the authors. Licensee MDPI, Basel, Switzerland. This article is an open access article distributed under the terms and conditions of the Creative Commons Attribution (CC BY) license (http://creativecommons.org/licenses/by/4.0/). 